\title{
Effects of the utilization of homeopathic elements in commercial diluent on swine sperm viability
}

\author{
Francisco Rafael Martins Soto • Erlete Rosalina Vuaden • Cideli de Paula Coelho • \\ Leoni Villano Bonamin - Sérgio Santos de Azevedo - Nilson Roberti Benites • \\ Flavia Regina Oliveira de Barros • Marcelo Demarchi Goissis • \\ Mayra Elena Ortiz D'Ávila Assumpção • José Antônio Visintin • \\ Mariana Groke Marques
}

Received: 22 April 2010 / Accepted: 26 January 2011 / Published online: 27 February 2011 / Editor: J. Denry Sato

(C) The Society for In Vitro Biology 2011

\begin{abstract}
It has been speculated that the homeopathic treatment of sperm cells in order to improve semen quality could be promising. However, few data is available and its use in spermatozoa requires investigation. It is well established that mitochondrial membrane potential is an important viability parameter of spermatozoa and it is intimately related to reproductive efficiency. In this manner, new technologies in order to improve the activity of sperm cells and, finally, the fecundity of swine herds are of extremely importance. Due to the lack of knowledge of homeopathic treatment effect on spermatozoa, the aim of the present study was to verify the effect of three different homeopathic treatments on viability of boar sperm cells. Three homeopathic treatments composed by Pulsatila CH6, Pulsatila and Avena CH6, Avena CH6 and one control treatment (sucrose) were added to diluted boar semen, which were cooled for 24 or $48 \mathrm{~h}$. Interestingly, no positive effect of homeopathic treatments was observed over
\end{abstract}

\section{F. R. M. Soto}

Center for Sanitary Surveillance and Zoonoses Control "Tereza

Rodrigues de Camargo",

Estrada da Vargem do Salto- Km 4,5- Bairro dos Paes,

18150-000 Ibiúna, São Paulo, Brazil

\section{E. R. Vuaden}

M Cassab- Animal Technology,

Avenida das Nações Unidas, 20.882,

04795-000 São Paulo, São Paulo, Brazil

C. de Paula Coelho $\cdot$ N. R. Benites $\cdot$ F. R. O. de Barros

M. D. Goissis • M. E. Ortiz D'Ávila Assumpção • J. A. Visintin

Department of Animal Reproduction, College of Veterinary

Medicine and Animal Sciences, University of Sao Paulo,

Avenida Prof. Dr. Orlando Marques de Paiva,

87, Cidade Universitária,

05508-900 São Paulo, São Paulo, Brazil semen viability. However, it was demonstrated that the $24 \mathrm{~h}$ of cooling storage provided more viable sperm cells when compared to the 48-h period. This effect of storage period on sperm viability was assessed by intact plasmatic membrane, intact acrosome and mitochondrial membrane potential evaluation.

Keywords Homeopathy $\cdot$ Swine semen $\cdot$ Sperm viability

Homeopathy is used in the treatment and prevention of many diseases in humans and animals, and studies have already confirmed its efficiency, it is object of various criticisms (Varshney and Naresh 2005; Vuaden 2005; Lobreiro 2007; Soto et al. 2007, 2009). Although there are few studies on the effect of homeopathic medicine directly applied to the semen in order to stimulate the

\section{V. Bonamin}

Faculty of Veterinary Medicine, Paulista University,

Avenida Prof. Dr. Orlando Marques de Paiva,

87, Cidade Universitária,

05508-900 São Paulo, São Paulo, Brazil

S. S. de Azevedo

Academic Unity of Veterinary Medicine,

University of Campina Grande,

Avenida Universitária, s/n, Bairro Santa Cecília, Caixa Postal 64, 58700-970 Patos, Paraíba, Brazil

M. G. Marques $(\square)$

EMBRAPA Swine and Poultry Research Center, BR 153, km 110, Tamandua,

89700-000 Concordia, Santa Catarina, Brazil

e-mail: marigroke@gmail.com 
activity of the sperm cells and the fecundity rate in swine herds (Soto et al. 2009), this seems to be a promising way to improve reproductive results.

Traditionally, the Avena sativa has been described as a homeopathic medicine which acts in various metabolic pathways, including male reproduction tract by acting positively on sperm cells (Demarque et al. 1997). Pulsatilla nigricans or Anemona pratensis, plant from Ranunculaceas family that grows in high mountains in Europe, has a beneficial effect on reproduction tract of domestic animals by increasing fertility (Montano 1981). In addition, satisfactory results have been obtained with homeopathy in humans and animals using $A$. sativa and/or P. nigricans in order to increase fecundity (Gerhar and Wallis 2002; Lobreiro 2007). For this reason, the use of homeopathy in routine semen manipulation in order to improve semen quality and fecundity is an interesting topic to investigate.

Swine industry is focused on increasing the number of weaned piglets per sow which will be converted in production of tons of meat per year (Wentz et al. 2001). This result is under strong influence of reproductive rates of swine raising. The artificial insemination with cooled diluted semen within $5 \mathrm{~d}$ after semen collection is a worldwide consolidated practice in swine herds (Flores et al. 2004). In this manner, investigations have been made to increase the swine sperm cell quality and, therefore, the parturition rate and number of newborn piglets (Bortolozzo and Wentz 1995; Flores et al. 2004; Roner et al. 2006).

Among viability indicators of sperm cells, the mitochondrial membrane potential and acrosome integrity can be highlighted as reliable indicators. It is well established that mitochondrial membrane potential is very important to a successful fertilization, which is intimately related to reproductive efficiency of boars (Spinaci et al. 2005). Sperm cells must present high motility to reach and fertilize the oocyte. The importance of sperm mitochondrial membrane potential relies on its dependence by motility. The classic method to evaluate mitochondrial membrane potential is to determine the percentage of motile cells under light microscopy. Although widely applied as a routine technique, the motility evaluation is an indirect method. The results obtained by means of this analysis show an inherent variability, given that samples are evaluated by different individuals, and that only few sperm numbers are analyzed (Meseguer et al. 2004). Some laboratories evaluate mitochondrial membrane potential staining sperm cells with a mitochondria-specific fluorescent dye to estimate semen quality. This technique allows a rapid and precise analysis of thousands of spermatozoa in each sperm sample.

High motility and high mitochondrial membrane potential alone do not guarantee the success of fertilization. The spermatozoon needs an intact acrosome membrane to trigger the acrosomal reaction, essential step to penetrate the zona pelucida of oocytes. In this manner, the assessment of acrosome membrane integrity represents an excellent indicator of semen quality.

Given the importance of mitochondrial membrane potential and acrosome membrane integrity as indicators of spermatozoa quality, the aim of the present study was to verify the effect of three different homeopathic treatments in diluted semen samples on viability of sperm cells.

For this, semen samples were obtained from two sexually mature boars (18 mo of age). The boars were cross bred, with similar genetics of Pietrain versus Duroc, BP 450 progeny from a supplier company of similar reproductive performance animals. The animals were maintained in individual stalls with controlled temperature and received food composed by $16 \%$ of raw protein from ground corn, soybean meal, corn germen, vitamins and mineral supplementation.

Sperm-rich fraction ejaculates were collected using the gloved hand procedure, performed once a week for $5 \mathrm{wk}$, providing a total of five ejaculates per animal. Each ejaculate was diluted in order to provide four semen samples. Semen samples were treated with Pulsatila CH6, Pulsatila and Avena CH6, Avena CH6 or control (sucrose).

The three homeopathic medicaments or the control were administrated as globules manipulated according Brazilian Homeopathic Pharmacology (Costa 1988; Farmacopeia Homeopática Brasileira 1998; Fontes 2001; Gutierrez et al. 2001). Each globule weighted $30 \mathrm{mg}$ and contained sucrose as vehicle. One dose of two globules was added per $100 \mathrm{~mL}$ of diluted semen. All samples were labeled in codes in order to allow all laboratory analysis and evaluations being performed as a blind test. Only the
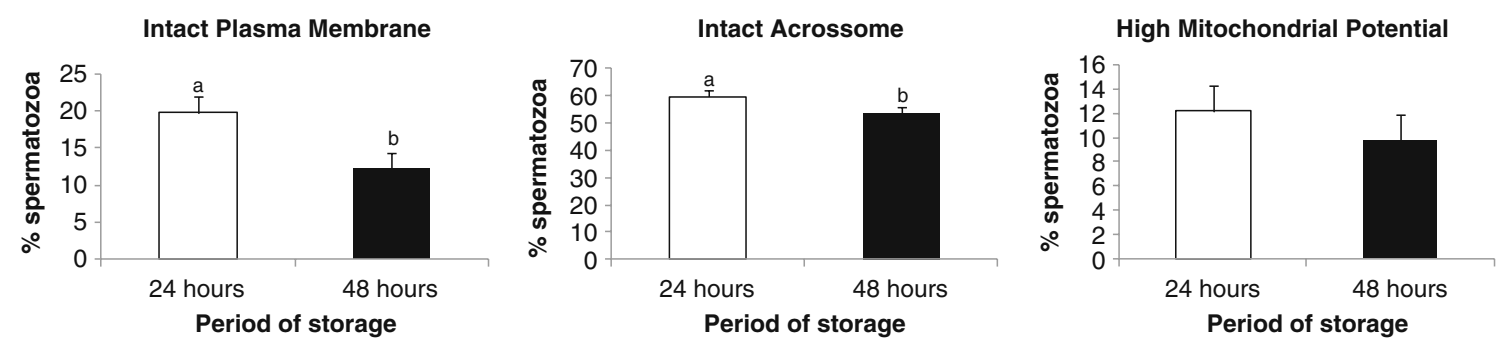

Figure 1. Effect of storage period (24 or $48 \mathrm{~h}$ ) on intact plasma membranes, intact acrossome, and high mitochondrial potential rates. 

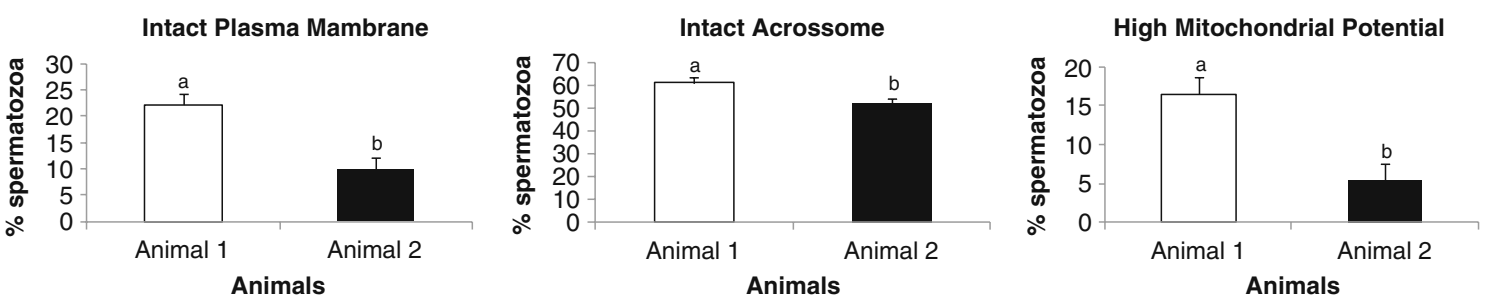

Figure 2. Effect of Animal on intact plasma membranes, intact acrossome, and high mitochondrial potential rates.

laboratory responsible by production of homeopathic medicaments, authorized by National Agency of Sanitary Surveillance had information of the code regarding the formulations. Semen samples were stored in $100 \mathrm{~mL}$ plastic vials at $15^{\circ} \mathrm{C}$ for $48 \mathrm{~h}$. One milliliter of refrigerated semen was collected at 24 and $48 \mathrm{~h}$ to assess semen viability.

The required parameters were minimum of $80 \%$ of sperm motility, three billions of sperm cells per $100-\mathrm{mL}$ vial of diluted semen and sperm vigor equal or higher than three (Bortolozzo and Irgang 2005). Sperm cell concentration was determined using a sperm densimeter (Minitüb ${ }^{\circledR}$, Abfül- und Labortechnik GmbH \& Co. KG, Germany).

Sperm motility was assessed using an optical microscope. Briefly, semen was diluted with the commercial diluent MIII ${ }^{\circledR}$ (Minitüb $^{\circledR}$, Abfül- und Labortechnik GmbH \& Co. KG, Germany) and one microdrop was placed between warm glass slide and cover slip. Motility was determined as the percentage of motile sperm cells. Right after motility evaluation and using the same slide, sperm vigor was numerically determined with a five-point score: 0 (dead sperm cells), 1 (low vigor), 2 (medium vigor), 3 (satisfactory vigor), and 4 (high vigor) (Johnston et al. 2001; Bortolozzo and Irgang 2005).

Plasma membranes and acrosome integrity and mitochondrial membrane potential were assessed with fluorescent probes: propidium iodide (PI), FITC-Pisum sativum agglutinin (FITC-PSA) and 5,5',6,6'- tetrachloro-1,1',3,3'tetraethylbenzimidazolylcarbocyanine iodide (JC1). After 24 or $48 \mathrm{~h}$ of incubation, $3 \mu \mathrm{L}$ de PI $(0.5 \mathrm{mg} / \mathrm{mL}$; SigmaAldrich Corp., St Louis, MO, USA), $50 \mu \mathrm{L}$ de FITC-PSA $(100 \mu \mathrm{g} / \mathrm{mL}$; Sigma), and $2 \mu \mathrm{L}$ of JC-1 (153 $\mu \mathrm{M}$; Molecular Probes, Invitrogen, Carlsbad, CA) were added to a $150 \mu \mathrm{L}$ aliquot from diluted semen.
Samples were incubated at $38.5^{\circ} \mathrm{C}$ for 8 min in the dark. Eight microliters of stained semen were placed on glass slide and covered with cover slip. Glass slides were immediately evaluated under epifluorescence microscopy (Olympus IX81, Center Valley, PA, EUA) using a double set of filters, PI (absorption, $536 \mathrm{~nm}$; emission, $617 \mathrm{~nm}$; red); FITC (absorption, $490 \mathrm{~nm}$; emission, $525 \mathrm{~nm}$; green); JC-1 (absorption, $514 \mathrm{~nm}$; emission, $529 \mathrm{~nm}$; green), at $\times 200$ of magnification.

A total of 200 spermatozoa per lamina were evaluated and classified as intact plasma membrane (negative IP) or damaged plasma membrane (positive IP, nucleus in red); intact acrosome (negative FITC-PSA) or damaged acrosome (positive FITC-PSA, acrosome in yellow/green), high mitochondrial membrane potential (positive JC-1, intermediate piece in red) or low (positive JC-1, intermediate piece in green).

Data were tested for normality of residues and homogeneity of variances using the Guided Data Analysis software. Variables and interactions were analyzed by the PROC MIXED of the SAS package (SAS Institute Ins. Cary, NC). Adjusted least squares means (LSMEANS) of treatments were compared using the Tukey Test.

Significance level to reject H0 (null hypothesis) was $5 \%$. Independent variables were storage period, animal, homeopathic treatment and their interactions. Dependent variables were plasmatic membrane integrity, acrosome integrity and high mitochondrial membrane potential.

These experiments were approved by bioethics committee of the College of Veterinary Medicine and Animal Sciences, University of Sao Paulo.

No interaction between storage period and animal was verified on intact plasmatic membrane percentage $(p=0.2)$,
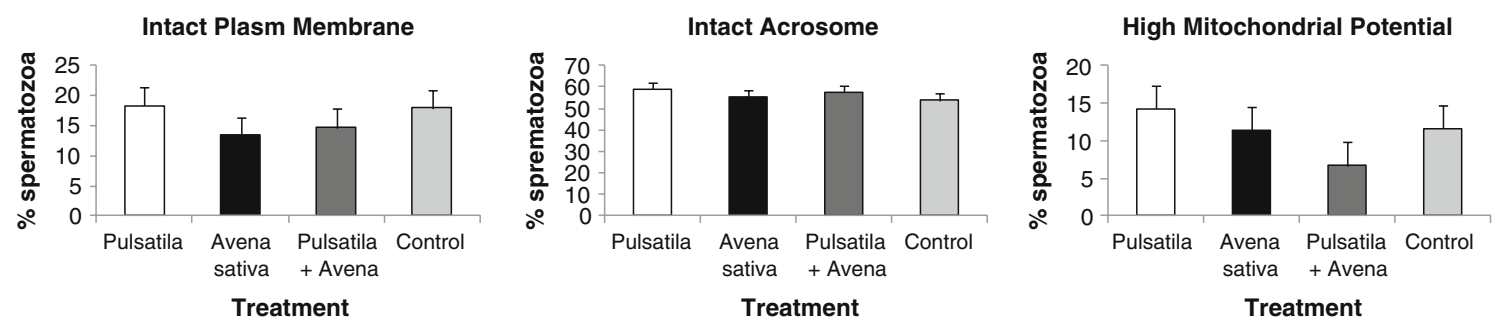

Figure 3. Effect of homeopathic (Pulsatila, Avena, Pulsatila+Avena) or control on intact plasma membrane, intact acrosome, and high mitochondrial potential rates. 
intact acrosome percentage $(p=0.27)$ and high mitochondrial membrane potential $(p=0.3)$. Moreover, no interaction between storage period and treatment was verified on intact plasmatic membrane percentage $(p=0.2)$, intact acrosome percentage $(p=0.11)$, and high mitochondrial membrane potential $(p=0.09)$. Also, no interaction between animal and treatment was verified on intact plasmatic membrane percentage $(p=0.49)$, intact acrosome percentage $(p=0.27)$, and high mitochondrial membrane potential $(p=0.91)$.

Storage period evaluation showed that $24 \mathrm{~h}$ of storage provided higher intact plasmatic membrane and intact acrosome percentages ( $p=0.016$ and 0.04 , respectively). However, no differences were observed for high mitochondrial membrane potential ( $p=0.41$; Fig. 1).

There was an effect of animal used in the seminal characterisitics evaluated (Fig. 2), however, no effect of homeopathic treatment was observed on percentage of intact plasmatic membrane $(p=0.60)$, percentage of intact acrosome $(p=0.63)$ and high mitochondrial membrane potential ( $p=0.36$; Fig. 3 ).

A previous study conducted by Soto et al. (2009) with $A$. sativa administrated in diluted swine semen, reported improvement in the fecundation process, reaching parturition rates greater than $80 \%$. In order to better understand these results, the present study was designed to verify the hypothesis that diluted swine semen treated with homeopathic compounds present more viable sperm cells. In this manner, the effects of three different homeopathic treatments, including A. sativa, were compared. Sperm cells viability was assessed by evaluating plasmatic membrane integrity, acrosome membrane integrity and mitochondrial membrane potential.

Others studies have already demonstrated the positive effect in the utilization of homeopathy in the semen of livestock animals and in the reproduction tract of sows. Aziz and Enbergs (2005) demonstrated that homeopathic treatment of cooled bovine semen with different monensin dilutions (5-14 times) resulted in a significant increase of mitochondrial membrane potential of sperm cells, measured by flow cytometry. In addition, no negative effects on semen viability were observed. Vuaden (2005) performed a study with swine farms of Sao Paulo State, Brazil, and an increase in parturition and newborn rates were observed by treating sows with homeopathic medicine, either individually or through feeding. Soto et al. (2010) demonstrated that $A$. sativa as a homeopathic preparation can be order to improve the parturition rate in technified swine farms.

Although it have been reported that homeopathic treated semen could improve pregnancy rates, the present study did not show any evidence of beneficial effects of homeopathic compounds on sperm cells viability. We compared Pulsatila CH6, Pulsatila and Avena CH6, Avena CH6 administrated at diluted semen from mature boars. No effect of treatments was observed on the studied parameters (plasmatic membrane integrity, acrosome membrane integrity and mitochondrial membrane potential).

However, it was observed that semen refrigerated for $24 \mathrm{~h}$ provide more viable sperm cells when compared to $48 \mathrm{~h}$ of cool storage. The plasmatic membrane integrity and acrosome membrane integrity evaluation suggested that longer periods of cool storage can increase the damage of these membranes. The keeping of intact acrosome is an essential element to a satisfactory fertilization process, resulting in the increase of parturition rate over $85 \%$ and more newborn piglets per sows (Spinaci et al. 2005). Interestingly, no difference was observed between the two periods of semen storage regarding mitochondrial membrane potential.

It is important to highlight that the treatment of sperm cells with homeopathy to improve its quality is new and promising. For this reason, further investigation is required.

\section{References}

Aziz D. M.; Enbergs H. Stimulation of bovine sperm mitochondrial activity by homeopathic dilutions of monensin. Homeopathy 94: 229-232; 2005.

Bortolozzo F. P.; Irgang I. Inseminação artificial na suinocultura tecnificada. Genamera Lima Jaques Pinto Editores, Rio Grande do Sul; 2005 .

Bortolozzo F. P.; Wentz I. Incremento da eficiência reprodutiva em programa de inseminação artificial no suíno. In: Congresso Brasileiro de Reprodução Animal. Colégio Brasileiro de Reprodução Animal, Belo Horizonte, pp 131-141; 1995.

Costa R. A. Homeopatia Atualizada. Homeopatia Escola Brasileira, Petrópolis; 1988.

Demarque D.; Jouanny J.; Poitevin B.; Saint-Jean Y. Farmacologia y Matéria Médica Homeopática. CEDH Edición Francesa, França; 1997.

Farmacopéia Homeopática Brasileira. Governo Federal, Brasília; 1998.

Flores L. A. S.; Wentz I.; Bortolozzo F. P. Comparação entre diferentes métodos de inseminação artificial em suínos. Ciênc. Rural 34: 1169-1175; 2004.

Fontes O. L. (2001) Farmácia Homeopática, Teoria e Prática. Editora Manole, São Paulo.

Gerhar I.; Wallis E. Individualized homeopathic therapy for male infertility. Homeopathy 91: 133-144; 2002.

Gutierrez M. A.; Silva M. L. F.; Moreira M. C.; Luna R., Maciel R. L.; Kazuma Y. Manual de Normas Técnicas de Farmácias Homeopáticas, $3^{\circ}$ edition. 2001: 190.

Johnston S. D.; Kustritz M. V. R.; Olson P. N. S. Semen collection, evaluation, and preservation. Canine and feline theriogenology. W.B. Saunders, Philadelphia; 2001.

Lobreiro J. Homeopathic treatment for infertility in a prize Nelore bull. Homeopathy 96: 49-51; 2007.

Meseguer M.; Garrido N.; Martínez-Conejero J. A.; Simo C.; Pellicer A.; Remoh J. Relationship between standard semen parameters, calcium, cholesterol contents, and mitochondrial activity in ejaculated spermatozoa from fertile and infertile males. J. Assist. Reprod. Genet. 21: 445-451; 2004.

Montano J. S. R. Pulsatilla and ovulation. Rev. Homeopat. 151: 31$32 ; 1981$. 
Roner M. N. B.; Silva Filho J. M.; Palhares M. S. Desenvolvimento de um sistema de resfriamento e conservação de sêmen suíno. Arq. Bras. Med. Vet. Zootec. 58: 78-86; 2006.

Soto F. R. M.; Coelho P. C.; Vuaden E. R.; Bonamin L. V.; Azevedo S. S.; Benites N. R.; Visintin, J. A.; De Barros, F. R. O.; Goissis, M. D.; Assumpção, M. E. O. A.; Marques, M. G.; Reproductive performance of sows inseminated with diluted semen treated with homeopathic medicine. International Journal of High Dilution Research 30: 51-57; 2010.

Soto F. R. M.; Vuaden E. R.; Benites N. R.; Azevedo S. S.; Pinheiro S. R.; Bernardi F.; Coelho C. P.; Vasconcellos S. A. Implantação da homeopatia e avaliação dos índices de mortalidade de uma granja comercial de suínos comparado com a alopatia nas fases de creche, recria e terminação. Vet. Zootec. 14: 107-114; 2007.

Soto F. R. M.; Vuaden E. R.; Coelho C. P.; Benites N. R.; Bonamim L. V.; Azevedo S. S. Effect of Avena sativa $\mathrm{CH} 6$ in the metabolism of diluted semen of swine. Vet. Zootec. 16: 367372; 2009 .

Spinaci M.; Ambrogi M.; Volpe S.; Galeati G. Effect of staining and sorting on boar sperm membrane integrity, mitochondrial activity and in vitro blastocyst development. Theriogenology 64: 191201; 2005.

Varshney J. P.; Naresh M. Comparative efficacy of homeopathic and allopathic systems of medicine in the management of clinical mastitis of Indian dairy cows. Homeopathy 94: 81-85; 2005.

Vuaden E. R. Homeopatia na Suinocultura. Monograph, Faculdade de Ciências da Saúde de São Paulo, Centro de Ensino Superior de Homeopatia, São Paulo; 2005.

Wentz I.; Bortolozzo F. P.; Brandt G. Hipertermia during estrus may influence the reproductive performance of female pigs. Cienc. Rural 31: 651-656; 2001. 